\title{
RESEARCH Note \\ Relations between fish length to weight, and otolith length and weight, of the lionfish Pterois volitans in the Parque Nacional Arrecife Alacranes, southern Gulf of Mexico
}

Relaciones entre longitud del pez al peso, y longitud de otolito y peso, del pez león Pterois volitans en el Parque Nacional Arrecife Alacranes, Sureste del Golfo de México

\section{Alfonso Aguilar-Perera ${ }^{1}$ and Luis Quijano-Puerto ${ }^{1}$}

\begin{abstract}
'Departamento de Biología Marina, Universidad Autónoma de Yucatán, Km. 15.5, carretera Mérida-Xmatkuil, A.P. 4-116 Itzimná, C.P. 97315, Universidad Autónoma de Yucatán, Mérida, Yucatán, México. alfaguilar@gmail.com
\end{abstract}

\begin{abstract}
Described are the relations between fish length to weight, and otolith length and weight, of the lionfish (Pterois volitans) collected by diver-fishermen volunteers between 2011 and 2013 in a natural protected area (Parque Nacional Arrecife Alacranes) off the northern Yucatan Peninsula, Mexico. High correlations were detected between fish length and otolith length. Significant differences in the length-weight relations were found for males and females. Length of lionfish can be estimated from otolith length and weight. This study will be helpful in diet content studies of potential predators of lionfish helping to discern the size of lionfish consumed when otoliths are found in stomachs of predators.
\end{abstract}

Key words: Pterois volitans, otolith fish-size relation, Yucatan Peninsula, Mexico

\section{INTRODUCTION}

The lionfish [Pterois volitans (Linnaeus, 1758): Scorpaenidae] is a predator native to the Indo-Pacific Ocean that was introduced by aquarium hobbyists into the Atlantic Ocean about 30 years ago. It experienced a rapid dispersal in the region, where it is now considered an invasive species (Whitfield et al. 2002) and a threat to local marine ecosystems because of its high density and voracious diet (Green et al. 2012a, Côté et al. 2013). Consequently, recording as much information as possible on its biology and ecology is important to further understand its invasion. In the Southern Gulf of Mexico, the lionfish was first detected off the northern Yucatan Peninsula by late 2009 (Aguilar-Perera \& Tuz-Sulub 2010) where it now occurs in high densities (López-Gómez et al. 2014).

In stomach content analyses, the identification and quantification of fish prey is difficult when specimens are partially or totally digested. Since sagittal otoliths are resistant to digestion, these structures can be used as reference for prey classification studies (Battaglia et al. 2010). Otoliths are calcium carbonate structures responsible for stability and sound detection in bony fishes (Campana 2004). Otoliths have distinctive shapes, which vary widely among fish families and can be highly species-specific (Harvey et al. 2000, Tuset et al. 2008). Among the 3 pairs of otoliths in bony fishes (asteriscus, lapillus, sagittae), sagittae are the largest (Harvey et al. 2000).
Knowing the relationship between sagittae otolith length and fish length provides important information to determine fish length from otoliths in stomach of predators and understand preypredator relationships (Granadeiro \& Silva 2000, Battaglia et al. 2010, Kasapoglu \& Duzgunes 2013). Using otoliths to infer length-weight relations in lionfish has never been attempted before. Consequently, by calculating these relations it would be possible to know the size of lionfish consumed by native fish predators in the invaded region based on the size of the lionfish otolith. In this sense, this study described relations between length, weight, and sagittal otolith dimensions of the lionfish from the Parque Nacional Arrecife Alacranes, off the northern Yucatan Peninsula in Mexico.

\section{MATERIALS AND METHODS}

Alacranes reef $\left(22^{\circ} 31^{\prime} 28^{\prime \prime} \mathrm{N}\right.$; 89 $\left.89^{\circ} 42^{\prime} 44^{\prime \prime} \mathrm{W}\right)$, the largest reef formation in the Southern Gulf of Mexico, is located $130 \mathrm{~km}$ off the northern Yucatan Peninsula, Mexico (Chávez et al. 2007). It is a natural protected area, known as the Parque Nacional Arrecife Alacranes (PNAA). It also serves as a commercially important fishery zone for the spiny lobster (Panulirus argus) where diver-fishermen catch lobster from July to February each year (Ríos-Lara et al. 2007). During a voluntary participation program, focused on lionfish removals 
in the PNAA, local diver-fishermen collected specimens using spear guns at depths ranging from $5 \mathrm{~m}$ to $20 \mathrm{~m}$ during common lobster fishing journeys (López-Gómez et al. 2014). Lionfish samples were collected between July 2011 and February 2013.

Lionfish were preserved frozen, kept in labeled polyethylene bags, and transported to the laboratory of the Campus of Biological and Agricultural Sciences of the Universidad Autónoma de Yucatán. At the laboratory, lionfish were taxonomically identified to species according to Schultz (1986). Fish total length (TL) was measured in millimeters using a graduated table and total weight $(\mathrm{W})$ recorded in grams using a TOREY electronic balance. When possible, i.e., fish were sexually active, individuals were sexed macroscopically following the criteria of Green et al. (2012b). All subsequent analyses were performed for all individuals combined as well as separately for sexed males and females. Sagittal otoliths were removed from all specimens following a procedure of cutting the otic capsule with a scalpel and using forceps (Aguilar-Perera et al. 2015). After removal, otoliths were cleaned and stored dry in labeled envelopes.

The relation between fish length and weight was calculated using a least-squares linear regression $(\mathrm{y}=a+b x)$ (Le Cren 1951, Froese 2006) based on logarithms for males, females, and all individuals combined. A Student's t-test was used to determine differences in length between males and females. A comparison of the regression slopes between males and females was performed with an Analysis of Covariance (ANCOVA). Otolith length was measured by analyzing digital images taken from an ocular micrometer mounted on a VELAB stereomicroscope and using a software program (TS-VIEW). Otolith length was recorded as the greatest distance measured from the anterior tip to the posterior edge, parallel to the sulcus (Harvey et al. 2000) with $0.01 \mathrm{~mm}$ of precision. There was no significant difference in length between the left and right otolith (t-test, $P=0.3325$ ); thus, the right otolith was used for all the analyses. Otolith weight was recorded with an OHAUS analytical balance to an accuracy of $0.0001 \mathrm{~g}$. The relations between fish length and otolith dimensions were calculated using a least-squares linear regression $(\mathrm{y}=a+b x)$ based on logarithms to determine what equations best described the following relations: otolith length to fish length, otolith weight to fish length, otolith weight to otolith length, and fish weight to otolith weight. Regression analyses were carried out using Statgraphics Centurion. Computations and statistical analyses were performed according to Sokal \& Rohlf (2012). The significance of the linear regressions was verified using the Ftest. Presence of outliers was taken into consideration according to Froese et al. (2011).

\section{RESULTS AND DISCUSSION}

A total of 472 lionfish were collected and had a mean total length of $228 \mathrm{~mm}$ TL and a mean weight of $235.6 \mathrm{~g}$, with a size range of 98 to $358 \mathrm{~mm}$ TL (Table 1, Fig. 1). A subsample of 126 lionfish was sexed and comprised of 59 males and 67 females (Table 2, Fig. 1). While no significant differences were detected between mean total lengths per sex (t-test, $P=0.332$ ), there were significant differences between the slopes of the length-weight relations of males and females (ANCOVA, $N=$ $131, \mathrm{~F}=354, P<0.05)$ (Table 2).

The otolith dimensions to fish length relations were generated separately according to sex and also combined (Table 3 ). All linear relations were significant $(P<0.05)$. The variable most related to fish length was otolith weight with $95 \%\left(r^{2}=0.95\right)$ with sexes combined. This relationship held true when lionfish

Table 1. Principal parameters recorded for Pterois volitans from the Parque Nacional Arrecife Alacranes, southern Gulf of Mexico. OL= otolith length, $\mathrm{OW}=$ otolith weight, $\mathrm{TL}=$ total fish length, $\mathrm{W}=$ total fish weight, $\mathbf{S D}=$ standard deviation, $\mathrm{mm}=$ millimeters, $\mathrm{g}=$ grams, $\mathrm{N}=$ Number of fish sampled. 'All fish' refers to both sexed and unsexed fish / Parámetros principales registrados para Pterois volitans del Parque Nacional Arrecife Alacranes, sureste del Golfo de México. $\mathrm{OL}=$ longitud de otolito, $\mathrm{OW}=$ peso de otolito, $\mathrm{TL}=$ largo total del pez, $\mathrm{W}=$ peso total del pez, $\mathrm{SD}=$ desviación estándar, $\mathrm{mm}=$ milímetros, $\mathrm{g}=$ gramos, $\mathrm{N}$ = número de peces muestreado. 'All fish' se refiere tanto a peces sexados como no sexados

\begin{tabular}{lcr}
\hline \multirow{2}{*}{ Parameter } & \multicolumn{2}{c}{ Value } \\
\cline { 2 - 3 } & \multicolumn{1}{c}{ Mean $\pm \mathrm{SD}$} & \multicolumn{1}{c}{ Range } \\
\hline Males (N=64) & $4.89 \pm 0.75$ & $3.03-6.41$ \\
OL [mm] & $0.008 \pm 0.002$ & $0.002-0.01$ \\
OW [g] & $259 \pm 43.26$ & $151-325$ \\
TL [mm] & $296 \pm 131.75$ & $64.4-588$ \\
W [g] & & \\
Females (N=67) & $5.052 \pm 0.86$ & $3.38-6.99$ \\
OL [mm] & $0.008 \pm 0.002$ & $0.003-0.01$ \\
OW [g] & $266 \pm 49.76$ & $152-345$ \\
TL [mm] & $349 \pm 182.81$ & $34-680$ \\
W [g] & & \\
All fish (N= 472) & & \\
OL [mm] & $4.51 \pm 1.04$ & $1.95-7.39$ \\
OW [g] & $0.007 \pm 0.005$ & $0.001-0.11$ \\
TL [mm] & $228 \pm 66.16$ & $98-358$ \\
W [g] & $235.6 \pm 182.8$ & $11.9-754$ \\
\hline
\end{tabular}




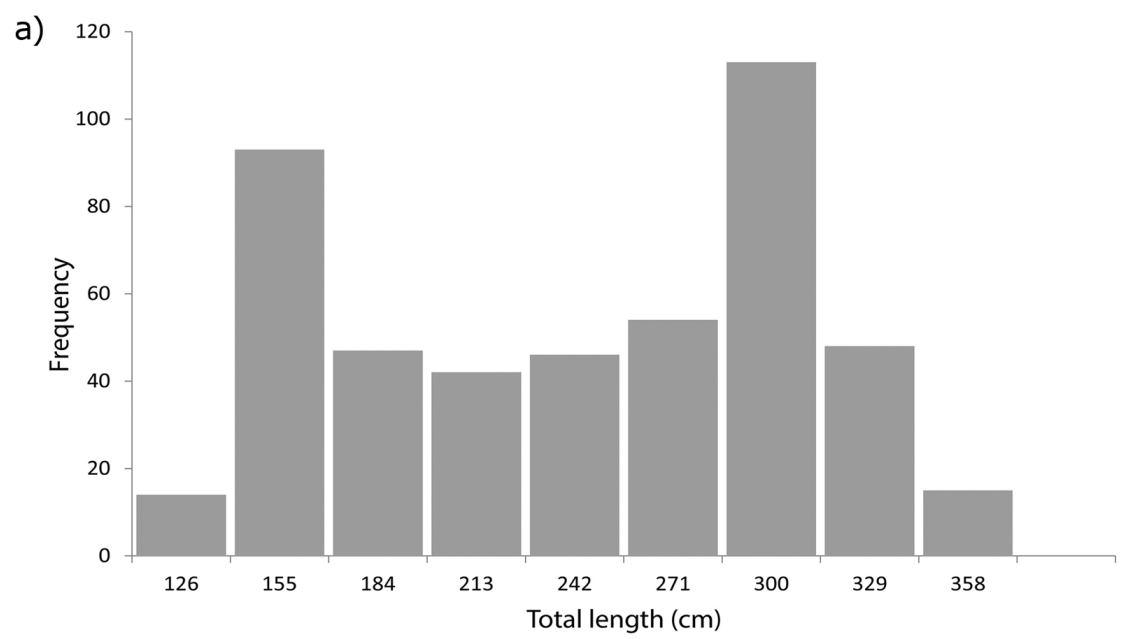

b)

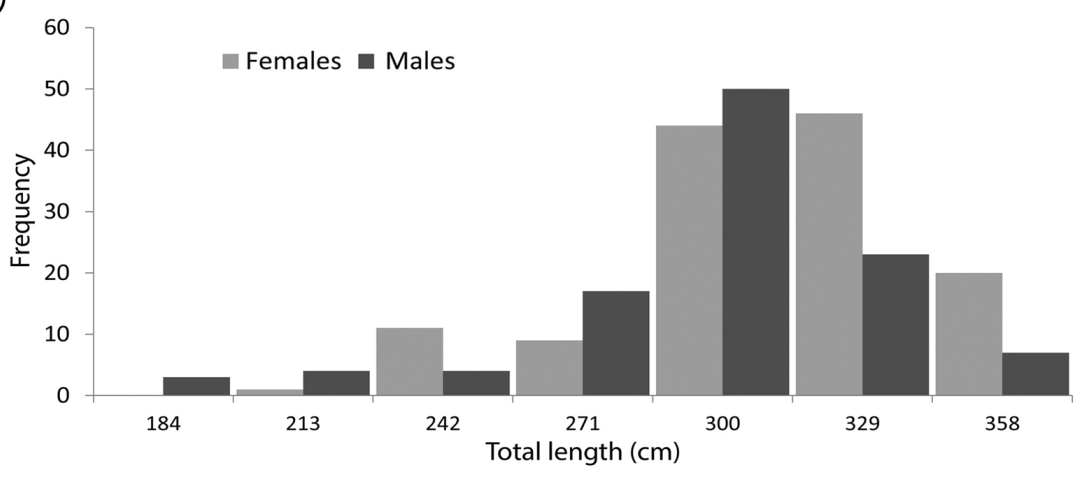

Figure 1. Length frequency of lionfish (Pterois volitans) from the Parque Nacional Arrecife Alacranes, southern Gulf of Mexico. a) All individuals ( $\mathrm{N}=$ 472), b) sexed individuals ( $\mathrm{N}=131$ ) / Frecuencias de longitud del pez león (Pterois volitans) del Parque Nacional Arrecife Alacranes, sureste del Golfo de México. a) todos los individuos $(\mathrm{N}=472)$, b) individuos sexados $(\mathrm{N}=131)$

Table 2. Linear relations $(y=a+b x)$ between total length and total weight of females, males, and combined (total fish sampled), of Pterois volitans from the Parque Nacional Arrecife Alacranes, southern Gulf of Mexico. TL=total length (of fish), $W=$ fish weight; $a=$ intercept value, $b=$ regression slope, $\mathrm{r}^{2}=$ coefficient of determination, $\mathrm{SD}=$ standard deviation, $\mathrm{N}=$ number of fish sampled, $\mathrm{Cl}=$ confidence interval, $\min =\operatorname{minim} u m, \max =\operatorname{maximum}$, $\mathbf{m m}=$ millimeters, $\mathbf{g = g r a m s . ~ ' A l l ~ f i s h ' ~ r e f e r s ~ t o ~ b o t h ~ s e x e d ~ a n d ~ u n s e x e d ~ f i s h ~ / ~ R e l a c i o n e s ~ l i n e a l e s ~}(y=a+b x)$ entre largo total y peso total de hembras, machos y combinados (todos los peces muestreados) de Pterois volitans del Parque Nacional Arrecife Alacranes, sureste del Golfo de México. TL= largo total (del pez), $\mathrm{W}=$ peso del pez, $\mathrm{a}=$ valor del intercepto, $\mathrm{b}=$ pendiente de la regresión, $\mathrm{r}^{2}=$ coeficiente de determinación, $S D=$ desviación estándar, $\mathrm{N}$ = número de peces muestreado, $\mathrm{Cl}=$ intervalo de confianza, $\mathrm{min}=$ mínimo, $\mathrm{max}=$ máximo, $\mathrm{mm}=$ milímetros, g= gramos. 'All fish' se refiere tanto a peces sexados como no sexados

\begin{tabular}{lcccccccc}
\hline Sex & $\mathrm{N}$ & $\begin{array}{c}\text { TL }(\mathrm{mm}), \text { mean SD } \\
(\min -m a x)\end{array}$ & $\begin{array}{c}\text { W (g), mean SD } \\
(\min -\max )\end{array}$ & $a$ & $b$ & CI 95\% $(a)$ & CI 95\% $(b)$ & $\mathrm{r}^{2}$ \\
\hline Females & 67 & $267 \pm 49.76(152-345)$ & $349 \pm 182.91(34-680)$ & -5.93 & 3.47 & $-5.16--3.94$ & $2.64-3.14$ & 0.95 \\
Males & 59 & $259 \pm 43.26(151-325)$ & $297 \pm 131.75(64-588)$ & -5.38 & 3.23 & $-6.41--5.48$ & $2.64-3.67$ & 0.95 \\
All fish & 472 & $228 \pm 66.16(98-358)$ & $235 \pm 182.87(12-754)$ & -2.24 & 3.30 & $-2.32--2.15$ & $3.24-3.36$ & 0.95 \\
\hline
\end{tabular}


Table 3. Linear relations $(y=a+b x)$ between length, weight and otolith dimensions of Pterois volitans from the Parque Nacional Arrecife Alacranes, Southern Gulf of Mexico. TL=total length (of fish), $O L=$ otolith length, $O W=$ otolith weight, $W=$ fish weight; $a=$ intercept value, $b=$ regression slope, $\mathbf{r}^{2}=$ coefficient of determination, $\mathrm{SE}=$ standard error of the mean, $\mathrm{N}=$ number of fish sampled, $\mathrm{Cl}=$ confidence interval. 'All fish' refers to both sexed and unsexed fish / Relaciones lineales $(y=a+b x)$ entre largo, peso y dimensiones de otolito de Pterois volitans del Parque Nacional Arrecife Alacranes, Sureste del Golfo de México. $T L=$ longitud total, $\mathrm{OL}=$ longitud del otolito, $\mathrm{W}=$ peso del pez, $a=$ valor de intercepto, $\mathrm{b}=$ pendiente de la regresión, $\mathrm{r}^{2}=$ coeficiente de determinación, $\mathrm{SE}=$ error estándar de la media, $\mathrm{N}=$ número de peces muestreado, $\mathrm{Cl}=$ intervalo de confianza. 'All fish' se refiere tanto a peces sexados como no sexados

\begin{tabular}{ccccccc}
\hline \multirow{2}{*}{ Relation } & \multicolumn{7}{c}{ Regression Parameters } \\
\cline { 2 - 7 } Males & $a( \pm \mathrm{SE})$ & $b( \pm \mathrm{SE})$ & CI $95 \%(a)$ & CI 95\% $(b)$ & $\mathrm{r}^{2}$ & $\mathrm{~N}$ \\
TL-OL & $1.76(0.042)$ & $0.93(0.062)$ & $1.68-1.85$ & $0.80-1.05$ & 0.80 & 57 \\
TL-OW & $3.47(0.035)$ & $0.50(0.016)$ & $3.40-3.55$ & $0.47-0.54$ & 0.95 & 47 \\
W-OW & $5.69(0.116)$ & $1.56(0.055)$ & $5.46-5.93$ & $1.45-1.67$ & 0.95 & 43 \\
OW-OL & $-2.84(0.791)$ & $1.10(0.113)$ & $-3.00--2.68$ & $0.88-1.33$ & 0.63 & 55 \\
W-OL & $0.55(0.132)$ & $2.75(0.190)$ & $0.28-0.81$ & $2.37-3.13$ & 0.80 & 52 \\
Females & & & & & \\
TL-OL & $1.67(0.048)$ & $1.03(0.068)$ & $1.58-1.77$ & $0.90-1.17$ & 0.80 & 58 \\
TL-OW & $3.60(0.042)$ & $0.56(0.020)$ & $3.52-3.69$ & $0.53-0.60$ & 0.95 & 53 \\
W-OW & $6.38(0.120)$ & $1.879(0.057)$ & $6.13-6.62$ & $1.76-1.99$ & 0.95 & 56 \\
OW-OL & $-3.299(0.057)$ & $1.69(0.081)$ & $-3.41--3.18$ & $1.53-1.86$ & 0.90 & 49 \\
W-OL & $-0.21(0.174)$ & $3.77(0.247)$ & $0.13--1.056$ & $4.27-3.28$ & 0.80 & 59 \\
All fish & & & & & & \\
TL-OL & $-1.01(0.023)$ & $0.71(0.010)$ & $-1.06--0.97$ & $0.69-0.63$ & 0.94 & 355 \\
TL-OW & $-6.21(0.048)$ & $1.70(0.020)$ & $-6.31--6.12$ & $1.66-1.74$ & 0.95 & 368 \\
W-OW & $6.23(0.046)$ & $1.81(0.021)$ & $6.14-6.32$ & $1.77-1.85$ & 0.95 & 382 \\
OW-OL & $-3.51(0.020)$ & $2.03(0.031)$ & $-3.55--3.47$ & $1.96-2.09$ & 0.93 & 331 \\
W-OL & $-0.38(0.052)$ & $3.99(0.080)$ & $-0.48--0.28$ & $3.83-4.15$ & 0.85 & 439 \\
\hline
\end{tabular}

were separated by sex (Table 3). ANCOVA showed significant differences between slopes of females and males for all regressions (Total Length to Otolith Length, $\mathrm{F}=61.38, P<$ 0.05; Total Length to Fish Weight, $\mathrm{F}=153.98, P<0.05$; Fish Weight to Otolith Weight, $\mathrm{F}=205.55, P<0.05$; Otolith Weight to Otolith Length, $\mathrm{F}=71.14, P<0.05$; Fish Weight to Otolith Length, $\mathrm{F}=59.28, P<0.05)$.

Verifying the presence of lionfish in stomach content studies of piscivorous fish is of relevance to determine potential predators of this invasive species. Based on Tuset et al. (2008) terminology of characteristics of fish otoliths, the sulcus acusticus is an important part of the otolith as some of its characteristics are among the most important features for fish species identification. According to observations made to lionfish otoliths in this study, the sulcus acusticus of the lionfish's otolith is heterosulcoid (ostium and cauda clearly differentiated but different in shape) with an ostial opening on supramedian position. The anterior and posterior regions of the otolith include some of the most important features for discriminating species using otolith morphology (Tuset et al. 2008). Lionfish's otolith is oblong, with an anterior and posterior regions peaked and crenate margins; the cauda is tubular and straight. 
In general, this work described the relations between length, weight, and otolith dimensions of the lionfish for the first time. Regression analyses have shown that correlations exist between lionfish length and otolith length, but also between fish length and otolith weight, and fish weight and otolith length. Results have shown that lionfish length can be estimated from otolith length and weight. Differences between fish dimensions according to sex can be attributed to physiological aspects; however, more data would be necessary to confirm this. Unfortunately, no other studies are available to compare the relations among these parameters for lionfish in other regions of its invaded range. The only previous study describing a length-weight relation for lionfish in the Southern Gulf of Mexico (Perera-Chan \& AguilarPerera 2012) did not describe the relation per sex or the otolith relation.

Otoliths are used in stomach content studies because they are among the species-specific features last to be digested by piscivorous predators (e.g., fish, sea birds, marine mammals); thus, otoliths can be used as a tool for reconstructing predator diet and estimating the size of preyed fish (e.g., Granadeiro \& Silva 2000, Harvey et al. 2000, Longenecker 2008, Kasapoglu \& Duzgunes, 2013, Lalas et al. 2014, Zan et al. 2015). Overall, the relations described in this work for lionfish in the PNAA can provide baseline data to detect lionfish presence and calculate its size based on otoliths found in stomachs of potential fish predators (i.e., groupers, snappers, jacks). So far, groupers (Epinephelidae) in coral reefs of The Bahamas have been detected as potential natural predators of lionfish in the Atlantic Ocean (Maljković et al. 2008, Mumby et al. 2011).

\section{ACKNOWLedGMENTS}

Lobster-diver fishermen provided lionfish samples from the Parque Nacional Arrecife Alacranes. Diana A. CoronadoRivera and Francisco J. Méndez-Anguiano helped in various ways. We thank Cristian Aguilar-Perera for redrawing the figure.

\section{LITERATURE CITED}

Aguilar-Perera A \& A Tuz-Sulub. 2010. Non-native, invasive red lionfish (Pterois volitans [Linnaeus, 1758]: Scorpaenidae), is first recorded in the southern Gulf of Mexico, off the northern Yucatan Peninsula, Mexico. Aquatic Invasions 5: S9-S12.

Aguilar-Perera A, L Quijano-Puerto \& E Carrillo-Flota. 2015. Manual of dissection techniques for the lionfish, Pterois volitans, from the Southern Gulf of Mexico, 36 pp. Fundación UADY-CONANP-CCBA, Universidad Autónoma de Yucatán, Mérida.
Battaglia P, D Malara, T Romeo \& F Andaloro. 2010. Relationships between otolith size and fish size in some mesopelagic and bathypelagic species from the Mediterranean Sea (Strait of Messina, Italy). Scientia Marina 74:605-612.

Campana SE. 2004. Photographic atlas of fish otoliths of the Northwest Atlantic Ocean, 284 pp. NRC Re-Search Press, Ottawa.

Chávez E, JW Tunnell \& K Withers. 2007. Reef zonation and ecology: Veracruz shelf and Campeche Bank. In: Tunnell JW, EA Chávez \& K Whiters (eds). Coral reefs of the southern Gulf of Mexico, pp. 41-67. Texas A\&M Press, College Station.

Côté IM, SJ Green \& MA Hixon. 2013. Predatory fish invaders: Insights from Indo-Pacific lionfish in the western Atlantic and Caribbean. Biological Conservation 164: 50-61.

Froese R. 2006. Cube law, condition factor and weight-length relationships: history, meta-analysis and recommendations. Journal of Applied Ichthyology 22: 241-253.

Froese R, AC Tsikliras \& KI Stergiou. 2011. Editorial note on weight-length relations of fishes. Acta Ichthyologica et Piscatoria 41: 261-263.

Granadeiro JP \& MA Silva. 2000. The use of otoliths and vertebrae in the identification and size-estimation of fish in predator-prey studies. Cybium 24: 383-393.

Green SJ, JL Akins \& IM Côté. 2012a. Invasive lionfish drive Atlantic coral reef fish declines. PLoS ONE 7, e32596. < http://dx.doi.org/10.1371/journal.pone.0032596>

Green SJ, JL Akins \& JA Morris Jr. 2012b. Lionfish dissection: Techniques and applications. NOAA Technical Memorandum NCCOS 139: 1-24.

Harvey JT, TR Loughlin, MA Perez \& DS Oxman. 2000. Relationship between fish size and otolith length for 63 species of fishes from the eastern North Pacific Ocean. NOAA/ National Marine Fisheries Service, Seattle. NOAA Technical Report NMFS 150: 1-36.

Kasapoglu N \& E Duzgunes. 2013. The relationship between somatic growth and otolith dimensions of Mediterranean horse mackerel (Trachurus mediterraneus) from the Black Sea. Journal of Applied Ichthyology 29: 230-233.

Lalas C, HM McConnell \& L Meynier. 2014. Estimating size of opalfish from otoliths: implications for analyses of New Zealand sea lion diet. New Zealand Journal of Marine and Freshwater Research 48: 1-14.

Le Cren ED. 1951. The length-weight relationship and seasonal cycle in gonad weight and condition in the perch (Perca fluviatilis). Journal of Animal Ecology 20: 201-219.

Longenecker K. 2008. Relationships between otolith size and body size for Hawaiian reef fishes. Pacific Science 62: 533539.

López-Gómez MJ, A Aguilar-Perera \& L Perera-Chan. 2014. Mayan diver-fishers as citizen scientists: Detection and monitoring of the invasive red lionfish in the Parque Nacional Arrecife Alacranes, southern Gulf of Mexico. Biological Invasions 16: 1351-1357. 
Maljković A, TE Van Leeuwen \& SN Cove. 2008. Predation on the invasive red lionfish, Pterois volitans (Pisces: Scorpaenidae), by native groupers in the Bahamas. Coral Reefs 27: 501-501.

Mumby PJ, AR Harborne \& DR Brumbaugh. 2011. Grouper as a natural biocontrol of invasive lionfish. PloS One 6, e21510. <http://dx.doi.org/10.1371/journal.pone.0021510>

Perera-Chan L \& A Aguilar-Perera. 2014. Length-weight and length-length relationships of the invasive red lionfish [Pterois volitans (Linnaeus, 1758): Scorpaenidae] in the Parque Nacional Arrecife Alacranes, Southern Gulf of Mexico. Journal of Applied Ichthyology 30: 202-203.

Ríos-Lara V, S Salas, J Bello-Pineda \& I Peniche-Ayora. 2007. Distribution patterns of spiny lobster (Panulirus argus) at Alacranes reef, Yucatan: Spatial analysis and inference of preferential habitat. Fisheries Research 87: 3545.

Schultz ET. 1986. Pterois volitans and Pterois miles: two valid species. Copeia 1986: 686-690.
Sokal RR \& FJ Rohlf. 2012. Biometry: the principles and practice of statistics in biological research, 937 pp. W. H. Freeman, New York.

Tuset VM, A Lombarte \& CA Assis. 2008. Otolith atlas for the western Mediterranean, north and central eastern Atlantic. Scientia Marina 72: 7-198.

Whitfield P, T Gardner, SP Vives, MR Gilligan, WR Courtenay, R Carleton \& JA Hare. 2002. Biological invasions of the Indo-Pacific lionfish Pterois volitans along the Atlantic coast of North America. Marine Ecology Progress Series 235: 289-297.

Zan X-X, C Zhang, B-D Xu \& C-L Zhang. 2015. Relationships between fish size and otolith measurements for 33 fish species caught by bottom trawl in Haizhou Bay, China. Journal of Applied Ichthyology 31:544-548.

Received 14 July 2015 and accepted 6 May 2016

Editor: Claudia Bustos D. 